\title{
PENERAPAN ANALISIS FAKTOR REDUCTION DALAM DETERMINASI IMPLEMENTASI STANDAR AKUNTANSI KEUANGAN ENTITAS MIKRO KECIL DAN MENENGAH (SAK EMKM)
}

\author{
Anna Apriana Hidayanti ${ }^{1}$, Agus Khazin Fauzi ${ }^{2}$, Baiq Desthania Prathama ${ }^{3}$ \\ 1,2,3Sekolah Tinggi Ilmu Ekonomi AMM
}

\section{ARTICLE INFO}

Article History:

Received: 17 September 2020

Accepted: 26 November 2020

Published: 05 December 2020

Keywords:

Implementation of $S A K$ EMKM, Educational Background, Human Resource Quality, Perception, and Socialization

\begin{abstract}
The current research was carried out to investigate the correlation of educational background, perceived usefulness, perceived ease of use, socialization and quality of human resources with (SAK-EMKM) Implementation by reducing variables to several factors using the factor analysis method. Data collection in this study with a questionnaire given to the owner of the by Micro, Small and Medium Enterprises (MSMB) in Mataram city and 40 UMKM samples were obtained using purposive sampling technique, factor analysis aim to reduce the dimensionality of a set of data and clearly designed with the objective to identify certain unobservable factors from the observed variables. The results of this study were formed into two factors: 1st factor is these factors are termed the perception of the owner of the by Micro, Small and Medium Enterprises (MSMB) formed from the perception and variables using SAK EMKM perception then against SAK-EMKM implementation has a positive effect. 2nd factor is these factor was human resources factors formed from the educational background variable and the quality of human resources variable and against SAK-EMKM implementation has positive correlation.
\end{abstract}

\section{ABSTRAK}

Penelitian ini bertujuan untuk mengetahui hubungan latar belakang pendidikan, persepsi kegunaan, persepsi kemudahan penggunaan, sosialisasi dan kualitas sumber daya manusia dengan penerapan (SAKEMKM) menggunakan metode analisis faktor dengan mereduksi variabel menjadi beberapa faktor. Pengumpulan data dalam penelitian ini dengan kuesioner yang diberikan kepada pemilik umkm di kota mataram dan melalui teknik purposive sampling diperoleh sampel sebanyak 40 UMKM. Analisis faktor sendiri bertujuan untuk mereduksi dimensi sekumpulan data dan dirancang dengan jelas dengan tujuan untuk mengidentifikasi faktor-faktor tertentu yang tidak dapat diamati dari variabel yang diamati, sehingga hasil penelitian ini menemukan bahwa dari kelima variabel independent yang diamati dalam penelitian ini terbentuk dua faktor yaitu faktor pertama terbentuk dari variabel persepsi kegunaan dan variabel persepsi kemudahan penggunaan dari SAK EMKM jika diberi nama faktor menjadi persepsi pelaku UMKM dengan korelasi yang positif terhadap Implementasi Standar Akuntansi Keuangan Entitas Mikro Kecil dan Menengah (SAK EMKM) kemudian faktor kedua terbentuk dari variabel latar belakang pendidikan dan kualitas SDM jika diberi nama faktor tersebut dapat diberi nama faktor SDM (sumber daya manusia) dengan korelasinya adalah positif terhadap Implementasi Standar Akuntansi Keuangan Entitas Mikro Kecil dan Menengah (SAK EMKM).

\section{How to Cite:}

Hidayanti, Anna Apriana, Agus Khazin Fauzi, Baiq Desthania Prathama. Penerapan Analisis Faktor Reduction dalam Determinasi Implementasi Standar Akuntansi Keuangan Entitas Mikro Kecil dan Menengah (SAK EMKM). Jurnal Ilmiah Wahana Akuntansi, 15(2), 163-183. https://doi.org/10.21009/ wahana. 15.024 


\section{PENDAHULUAN}

Salah satu sektor usaha sebagai roda penggerak perekonomian bangsa yang telah berkontribusi dalam menyediakan lapangan pekerjaan bagi masyarakat dan menyumbang bagi produk domestik bruto (PDB) adalah usaha mikro, kecil dan menengah (UMKM). Hal ini dikarenakan bahwa ketika krisis moneter terjadi pada tahun 1998 dan ketika terjadi krisis global pada tahun 2008 ternyata UMKM mampu bertahan bahkan cenderung meningkat jumlahnya dikarenakan beberapa hal sebagaimana dikemukakan oleh (Partomo \& Soejoedono, 2002) : (1) sebagian besar UMKM memproduksi barang konsumsi dan jasa dengan elastisitas permintaan terhadap pendapatan yang rendah; (2) sebagan besar pelaku UMKM tidak ditopang dana pinjaman dari bank dan menggunakan modal sendiri; (3) pelaku UMKM umumnya memanfaatkan sumber daya lokal sehingga ketika sektor formal banyak memberhentikan pekerjanya, justru para pengangguran dapat memasuki sektor informal dengan melakukan kegiatan usaha berskala kecil.

Data Kementerian Koperasi, Usaha Kecil dan Menengah mencatat perkembangan jumlah UMKM di Indonesia selama 3 tahun terakhir mengalami peningkatan cukup signifikan sebagaimana halnya di Nusa Tenggara Barat (NTB) berdasarkan data Dinas Koperasi UKM Provinsi NTB yang dikutip dari situs http:// diskop.ntbprov.go.id/ mencatat jumlah UMKM pada tahun 2016 sebesar 646.424 unit, tahun 2017 sebesar 648.413 unit dan di tahun 2018 sebesar 648.573 unit. Perkembangan sektor UMKM tersebut memperlihatkan bahwa UMKM memiliki potensi besar untuk dikelola dan dikembangkan dengan baik sehingga dapat mewujudkan UMKM yang tangguh (Dewi et al., 2017). Menurut (Anisykurlillah \& Rezqika, 2019) bahwa perkembangan UMKM yang cukup signifikan tersebut akan menimbulkan masalah ketika terjadi persaingan yang semakin tinggi dan ketat yang membuat pelaku UMKM membutuhkan dana besar untuk melakukan inovasi dalam pengembangan usahanya mengingat saat ini Indonesia sudah menghadapi era Masyarakat Ekonomi Asean (MEA).

Menyambung hal tersebut di atas, pemerintah memang telah memberikan bantuan pendanaan dan memfasilitasi umkm untuk memperoleh kredit dengan melibatkan peran perbankan dalam penyaluran kredit tersebut melalui Peraturan Bank Sentral Nomor 14/22/ PBI/2012 Tentang Pemberian Kredit Oleh Bank Umum Dan Bantuan Teknis Dalam Rangka Pengembangan Usaha Mikro, Kecil Dan Menengah. Adapun tujuan hal itu adalah membantu UMKM dalam meningkatkan pengelolaan usahanya. Namun, berdasarkan observasi menunjukkan bahwa banyak pelaku UMKM masih minim dalam mengakses keuangan tersebut dikarenakan adanya kendala yang salah satunya adalah belum tersedianya laporan keuangan ataupun tidak menyelenggarakan praktik akuntansi dengan baik dan teratur seperti pencatatan dalam pengelolaan usahanya (Awalia et al., 2018). Padahal dalam memperoleh tambahan modal, pihak bank tidak melihat perbedaan antara usaha besar dan UKM namun dituntut menyertakan laporan keuangan sebagai syarat 
pengajuan kredit (Tarmizi \& Bugawanti, 2013).

Dalam Peraturan Pemerintah Republik Indonesia Nomor 17 Tahun 2013 tentang pelaksanan Undang-Undang Nomor 20 Tahun 2008 tentang Usaha Mikro, Kecil dan Menengah mewajibkan usaha kecil untuk melakukan pencatatan akuntansi. Sebab informasi keuangan dalam catatan akuntansi sangatlah penting untuk mengetahui proses pengembangan usaha dan untuk mencapai keberhasilan usaha (Pinasti, 2007). Dewan Standar Akuntansi Keuangan (DSAK) juga telah menyusun dan mengesahkan Standar Akuntansi Keuangan Entitas Tanpa Akuntabilitas Publik (SAK ETAP) yang efektif berlaku pada tanggal 1 Januari 2011 dengan harapan pengesahan standar tersebut dapat meningkatkan kualitas laporan UMKM. Namun nyatanya, beberapa penelitian mengungkapkan bahwa meskipun sudah ada aturan yang mengatur, praktik akuntansi pada UMKM masih terbilang rendah dan belum sesuai dengan standar akuntansi yang berlaku (Lutfiaazahra, 2015; Rudiantoro \& Siregar, 2012; Soraya \& Mahmud, 2016). Rendahnya implementasi standar tersebut dikarenakan sebagian besar UMKM menganggap pembukuan adalah hal yang rumit, memberatkan dan pencatatan akuntansi hanya membuang waktu dan biaya. Dengan demikian, implementasi SAK ETAP dirasakan belum optimal dan belum dimanfaatkan dengan baik oleh pelaku UMKM karena SAK ETAP dianggap masih terlalu kompleks, terlalu berat untuk diterapkan dan tidak sesuai dengan kebutuhan keuangan yang dimiliki oleh UMKM sehingga melihat kondisi itu, DSAK kemudian menyusun standar akuntansi baru yaitu Standar Akuntansi Keuangan Entitas Mikro, Kecil dan Menengah (SAK EMKM) yang berlaku efektif per tanggal 1 Januari 2018 yang ditujukan untuk UMKM secara menyeluruh agar UMKM dapat menyusun laporan keuangan yang berkualitas.

Walaupun sudah ada aturan yang jelas dan mudah bagi UMKM, ternyata implementasi SAK EMKM bagi pelaku UMKM masih juga terbilang rendah dikarenakan pemahaman pembukuan berdasarkan SAK EMKM masih minim sebagaimana hasil temuan penelitian yang dilakukan (Kirowati \& Amir, 2019; Prajanto \& Septriana, 2018). Merujuk hal tersebut, banyak peneliti yang telah melakukan penelitian untuk mengetahui faktor apa saja yang mempengaruhi pelaku UMKM dalam mengimplementasikan standar akuntansi dalam penyusunan laporan keuangan, seperti penelitian (Adino, 2019; Kusuma \& Lutfiany, 2018; Pratiwi \& Hanafi, 2016; Sariningtyas \& $\mathrm{W}$, 2011) mengungkapkan bahwa semakin tinggi tingkat pendidikan pemilik UMKM maka semakin mudah pemilik UMKM untuk menyerap informasi dan mengimplementasikan standar akuntansi keuangan dalam penyusunan laporan keuangan. Tidak hanya itu saja, pemilik UMKM yang mempunyai latar belakang pendidikan akuntansi juga cenderung akan menggunakan standar akuntansi dalam penyusunan laporan keuangan dikarenakan pemahaman mengenai bisnis semakin baik. Namun, disisi lain penelitian dari (Mubiroh \& Ruscitasari, 2020; Munandar \& Hidayatulloh, 2019; Prajanto \& Septriana, 2018) justru menemukan bahwa jenjang atau tingkat 
pendidikan tidak berpengaruh terhadap implementasi standar akuntansi keuangan.

Faktor lain yang juga memengaruhi implementasi SAK EMKM adalah kualitas sumber daya manusia. Kualitas sumber daya manusia identik dengan kompetensi yang dimiliki. Dalam human capital theory yang dikembangkan oleh Becker \& Grey (1962) dan dikutip oleh (Adino, 2019; Anisykurlillah \& Rezqika, 2019) berpendapat bahwa manusia itu merupakan suatu bentuk kapital atau barang modal sebagaimana barang-barang modal lainnya seperti tanah, gedung, mesin dan sebagainya dimana investasi sumber daya manusia mempunyai pengaruh besar terhadap peningkatan produktivitas sebuah usaha sehingga implementasi SAK ETAP dapat terlaksana apabila adanya sumber daya manusia yang mendukung sebagaimana hasil temuan (Minarni \& Sisdiyantoro, 2014) bahwa kompetensi sumber daya manusia berpengaruh signifikan terhadap implementasi SAK ETAP. Di dukung oleh hasil penelitian dari (Oktaviyanti et al., 2017) bahwa kompetensi sumber daya manusia berpengaruh terhadap kualitas laporan keuangan. Dengan demikian, untuk menghasilkan laporan keuangan yang berkualitas dibutuhkan sumber daya manusia yang berkompeten yang memahami standar akuntansi keuangan.

Dalam implementasi SAK EMKM, persepsi pelaku UMKM juga turut mempengaruhi. Menurut (Dewi et al., 2017; Tarmizi \& Bugawanti, 2013) bahwa setiap pemilik memiliki persepsi yang berbeda mengenai penggunaan SAK yang berlaku. Persepsi merupakan bagaimana orang-orang melihat atau menginterpretasikan baik peristiwa, objek maupun manusia. Schiffman dan Kanuk (2010) yang dikutip dari (Rudiantoro \& Siregar, 2012) juga mengemukakan bahwa pelaku UMKM dapat memiliki informasi yang berbeda dalam menginterpretasikan nilai informasi akuntansi sebab persepsi itu sendiri merupakan suatu proses dari individu dalam memilih, mengelola dan menginterprestasikan suatu rangsangan yang diterimanya ke dalam suatu penilaian terkait apa yang ada di sekitarnya sehingga persepsi merupakan suatu titik awal bagi seseorang untuk melakukan sesuatu hal, termasuk pandangan dari pengusaha UMKM mengenai pentingnya pembukuan dan pelaporan keuangan berdasarkan standar akuntansi yang berlaku. Penelitian (Kusuma \& Lutfiany, 2018) yang didukung oleh penelitian (Dewi et al., 2017) membuktikan bahwa persepsi pelaku UMKM berpengaruh dalam implementasi SAK EMKM.

Penelitian ini menarik untuk dikaji dikarenakan bahwa dengan banyaknya variabel yang dapat dijadikan indikator yang mempengaruhi Implementasi Standar Akuntansi Keuangan Entitas Mikro Kecil dan Menengah (SAK EMKM) sehingga terbentuk faktor yang merupakan gabungan dari beberapa variabel yang telah ditentukan sehingga penelitian ini bertujuan untuk (1) menganalisis apakah variabel dalam Implementasi Standar Akuntansi Keuangan Entitas Mikro Kecil dan Menengah (SAK EMKM) Pada Usaha Mikro Kecil Menengah (UMKM) Di Kota Mataram dapat di reduksi menjadi satu atau lebih faktor 
dengan menggunakan metode analisis faktor, (2) untuk mengetahui dan menganalisis apakah faktor-faktor yang terbentuk memiliki korelasi positif atau negatif dalam Implementasi Standar Akuntansi Keuangan Entitas Mikro Kecil dan Menengah (SAK EMKM) Pada Usaha Mikro Kecil Menengah (UMKM) Di Kota Mataram.

\section{TINJAUAN TEORI}

\section{Standar Akuntansi Keuangan Entitas Mikro, Kecil, dan Menengah (SAK EMKM)}

Berdasarkan Undang-Undang Nomor 20 Tahun 2008 tentang Usaha Mikro, Kecil dan Menengah, dapat dijelaskan bahwa klasifikasi UMKM dapat dibedakan dari jumlah aset dan total omzet penjualannya. Pemberdayaan UMKM perlu diselenggarakan secara menyeluruh, optimal, dan berkesinambungan melalui pengembangan iklim yang kondusif, pemberian kesempatan berusaha, dukungan, perlindungan, dan pengembangan usaha seluas-luasnya, sehingga mampu meningkatkan kedudukan, peran, dan potensi Usaha Mikro, Kecil, dan Menengah dalam mewujudkan pertumbuhan ekonomi,pemerataan dan peningkatan pendapatan rakyat, penciptaan lapangan kerja, dan pengentasan kemiskinan.

Menyambung hal di atas, bahwa dalam rangka membantu UMKM memenuhi kebutuhan pelaporan keuangannya, Dewan Standar Akuntansi Keuangan Ikatan Akuntan Indonesia (DSAK IAI) pada tahun 2016 telah menyusun dan mengesahkan Standar Akuntansi Keuangan Entitas Mikro, Kecil dan Menengah (SAK EMKM). Penerbitan SAK EMKM ini sebagai bentuk dukungan IAI sebagai organisasi profesi akuntan, dalam meningkatkan penegakan transparansi dan akuntabilitas pelaporan keuangan entitas sekaligus mendorong pertumbuhan sektor UMKM di Indonesia. Entitas Mikro, Kecil dan Menengah (EMKM) adalah entitats tanpa akuntabilitas publik yang signifikan sebagaimana didefinisikan dalam SAK ETAP, yang memenuhi definisi dan kriteria usaha mikro, kecil dan menengah sebagaimana diatur dalam peraturan perundangundangan yang berlaku di Indonesia, setidaktidaknya selama 2 tahun berturut-turut. SAK EMKM memuat pengaturan akuntansi yang lebih sederhana dari SAK ETAP karena mengatur transaksi yang umum dilakukan oleh EMKM dan dasar pengukurannya murni menggunakan biaya historis. Laporan keuangan minum yang disajikan terdiri dari laporan posisi keuangan pada akhir periode, laporan laba rugi selama periode, catatan atas laporan yang berisi tambahan dan rincian pos-pos tertentu yang relevan. Penyusunan laporan keuangan yang sesuai dengan standar akuntansi haruslah memenuhi karakteristik kualitatif informasi yang dipersyaratkan yaitu dapat dipahami, relevan, materialitas, keandalan, substansi mengguli bentuk, pertimbangan sehat, kelengkapan dapat dibandingkan, tepat waktu dan keseimbangan antara biaya dan manfaat (IAI, 2009).

\section{Latar Belakang Pendidikan}

Undang-Undang RI Nomor 20 Tahun 2003 menjelaskan tentang pendidikan sebagai usaha sadar dan terencana untuk mewujudkan suasana belajar dan proses pembelajaran agar 
peserta didik secata aktif mengembangkan potensi dirinya untuk memiliki kekuatan spiritual keagamaan, pengendalian diri, kepribadian, kecerdasan, akhlak mulia serta keterampilan yang diperlukan dirinya, masyarakat, bangsa dan negara. Jalur pendidikan terdiri atas pendidikan formal, non formal dan informal yang dapat saling melengkapi. Jenjang pendidikan formal terdiri atas pendidikan dasar, pendidikan menengah dan pendidikan tinggi. Pendidikan formal disini diperoleh di bangku sekolah sampai dengan Universitas. Pendidikan non formal meliputi pendidikan kecakapan hidup, pendidikan anak usia dini, pendidikan kepemudaan, pendidikan pemberdayaan perempuan, pendidikan keaksaraan, pendidikan keterampilan dan pelatihan kerja, pendidikan kesetaraan, serta pendidikan lain yang ditujukan untuk mengembangkan kemampuan peserta didik melalui kursus-kursus ataupun pelatihan yang diselenggarakan oleh pihak swasta maupun lembaga pemerintah. Sementara itu, pendidikan informal merupakan kegiatan belajar secara mandiri yang dilakukan oleh keluarga dan lingkungan.

Tingginya tingkat pendidikan masyarakat penting bagi kesiapan menghadapi tantangan global dikarenakan pendidikan yang lebih tinggi memudahkan seseorang untuk menyerap informasi dan mengimpelementasikannya (Nurdwijayanti \& Sulastiningsih, 2018). Begitu juga dengan apa yang disampaikan oleh (Tambunan, 2009) menyatakan bahwa semakin tinggi tingkat pendidikan rata-rata pekerja di suatu perusahaan maka akan semakin tinggi daya saing perusahaan tersebut sehingga perlu bagi pengelola perusahaan seperti UMKM untuk lebih meningkatkan kemajuan perusahaan termasuk melaksanakan pembukuan dan pelaporan keuangan secara rutin sesuai dengan standar yang telah ditetapkan yaitu SAKEMKM. Menurut human capital theory yang dikutip dari (Adino, 2019) mengungkapkan bahwa pendidikan dapat menanamkan ilmu pengetahuan, keterampilan dan nilai-nilai kepada manusia dan karenanya mereka dapat meningkatkan kapasitas belajar dan produktivitas. Hal ini bermakna bahwa tingkat pendidikan pemilik mempengaruhi kebutuhan informasi akuntansi keuangan dan manajemen. Dengan kata lain, pemahaman yang lebih baik mengenai SAK EMKM dapat dipengaruhi dari jenjang atau tingkat pendidikan sebagaimana hasil penelitian (Kusuma \& Lutfiany, 2018) membuktikan bahwa tingkat pendidikan pemilik berpengaruh terhadap implementasi SAK EMKM. Didukung pula oleh penelitian (Adino, 2019; Pratiwi \& Hanafi, 2016; Sariningtyas \& W, 2011).

Berdasarkan uraian di atas menunjukkan bahwa dalam teori dan hasil penelitian terdahulu, latar belakang pendidikan berpengaruh terhadap implementasi SAK EMKM sehingga diasumsikan variabel latar belakang pendidikan akan tereduksi dalam faktor yang terbentuk dalam analisis faktor, sehingga hipotesis awal dalam KMO dan barlett's test harus terpenuhi dengan asumsi :

$\mathrm{H}_{0}=$ Variabel latar belakang pendidikan belum memadai untuk dianalisis lebih lanjut.

$\mathrm{H}_{1}=$ Variabel latar belakang pendidikan sudah memadai untuk dianalisis lebih lanjut. 


\section{Kualitas Sumber Daya Manusia}

Pada dasarnya sumber daya manusia merupakan salah satu faktor yang sangat penting dalam suatu perusahaan. Untuk menilai kapasitas dan kualitas sumber daya manusia dalam melaksanakan suatu fungsi termasuk akuntansi dapat dilihat dari kompetensi sumber daya manusia. Kompetensi sumber daya manusia merupakan karakteristik dari seseorang yang memiliki keterampilan (skill), pengetahuan (knowledge) dan kemampuan (ability) (Minarni \& Sisdiyantoro, 2014). Adanya perubahan standar yang berlaku, menyebabkan pemilik ataupun karyawan haruslah memiliki sumber daya manusia yang berkualitas yaitu kompeten di bidangnya. Hal ini dikarenakan bahwa kualitas laporan keuangan akan meningkat apabila didukung oleh personel yang memahami standar akuntansi keuangan. Kualitas personel yang terlibat dalam penyusunan laporan keuangan harus mengerti dan memahami bagaimana proses dan pelaksanaan akuntansi itu dijalankan dengan berpedoman pada prinsip dan standar penyusunan laporan keuangan yang diterapkan dalam Standar Akuntansi Keuangan Entitas Mikro Kecil dan Menengah (SAK EMKM). Dengan demikian, ketika kualitas sumber daya manusia semakin baik yang dimiliki oleh pelaku UMKM maka berdampak pula kepada semakin baiknya implementasi yang dilakukan dari segala ketentuan yang ada dalam SAK EMKM sebagaimana hasil temuan (Minarni \& Sisdiyantoro, 2014) dan sejalan dengan hasil penelitian (Oktaviyanti et al., 2017).

Berdasarkan uraian di atas menunjukkan bahwa dalam teori dan hasil penelitian terdahulu, kualitas sumber daya manusia berpengaruh terhadap implementasi SAK EMKM sehingga diasumsikan variabel kualitas sumber daya manusia akan tereduksi dalam faktor yang terbentuk dalam analisis faktor, sehingga hipotesis awal dalam KMO dan barlett's test harus terpenuhi dengan asumsi :

$\mathrm{H}_{0}=$ Variabel kualitas sumber daya manusia belum memadai untuk dianalisis lebih lanjut.

$\mathrm{H}_{1}=$ Variabel kualitas sumber daya manusia sudah memadai untuk dianalisis lebih lanjut.

\section{Persepsi Pelaku UMKM}

Persepsi menurut (Lutfiaazahra, 2015) yang mengutip dari Harisah dan Masiming (2008) menyatakan bahwa perception adalah kegiatan merasakan atau kemampuan untuk merasakan, memahami jiwa dari objek-objek, kualitas dan lain-lain melalui pemaknaan rasa, kesadaran, perbandingan, pengetahuan yang dalam, intuisi ataupun kemampuan panca indera dalam memahami setua; pengertian, pengetahuan dan lain-lain yang diterima dengan cara merasakan, atau ide khusus, konsep, kesan dan lain-lain yang terbentuk. (Robbins, 2002) mengemukakan bahwa pada umumnya persepsi dipengaruhi oleh dua faktor yaitu faktor internal seperti sikap, kebiasaan, dan kemauan serta faktor eksternal yang berasal dari luar individu. Dijelaskan lebih lanjut, meskipun individu memandang pada satu benda yang sama, mereka dapat mempersepsikannya berbeda dikarenakan oleh 1) Pelaku persepsi; 2) Objek atau yang dipersepsikannya; dan 3) Keadaan 
dimana persepsi itu dilakukan. Dengan demikian, persepsi merupakan suatu titik awal bagi seseorang untuk melakukan sesuatu hal termasuk dalam membuat pembukuan dan pelaporan keuangan sesuai standar.

Untuk menyusun laporan keuangan agar sesuai dengan SAK menurut (Kusuma \& Lutfiany, 2018) perlu sekiranya mengubah persepsi para pelaku UMKM dikarenakan bahwa adanya persepsi yang baik maka dapat menjadikan persepsi tersebut sebagai penerimaan dan evaluasi untuk menjadikan usaha lebih baik dari sebelumnya. Persepsi berkaitan dengan bagaimana orang melihat atau menginterpretasikan suatu objek maupun peristiwa. Dengan demikian, persepsi seseorang timbul karena adanya beberapa stimulus yang mempengaruhi persepsi seperti sikap, kebiasaan maupun kemauan dimana jika implementasi SAK EMKM ketika dirasa memudahkan dan memberikan kegunaan untuk menghasilkan laporan keuangan yang berkualitas maka pemilik UMKM dapat mengimplementasikan SAK tersebut. Sebagaimana hasil penelitian yang dilakukan oleh (Kusuma \& Lutfiany, 2018) membuktikan bahwa persepsi pelaku UMKM berpengaruh positif dan signifikan terhadap implementasi SAK EMKM. Didukung pula oleh penelitian (Dewi et al., 2017; Tarmizi \& Bugawanti, 2013) bahwa persepsi pelaku UMKM berpengaruh terhadap penggunaan standar akuntansi keuangan yang berlaku.

Berdasarkan uraian di atas, persepsi kemudahan dan kegunaan dalam implementasi SAK EMKM terbagi menjadi dua variabel karena memiliki indikator pengukuran yang berbeda, namun dalam prinsipnya persepsi kemudahan dan kegunaan dalam implementasi SAK EMKM sangat berpengaruh dan diasumsikan kedua variabel ini akan terbentuk menjadi satu faktor dalam tahapannya, sehingga hipotesis awal dalam KMO dan barlett's test harus terpenuhi dengan asumsi :

$\begin{aligned} \mathrm{H}_{0}= & \text { Variabel persepsi kemudahan dan } \\ & \text { kegunaan belum memadai untuk } \\ & \text { dianalisis lebih lanjut. }\end{aligned}$

$\mathrm{H}_{1}=$ Variabel persepsi kemudahan dan kegunaan sudah memadai untuk dianalisis lebih lanjut.

\section{Sosialisasi}

Pada dasarnya sosialisasi adalah pemberian informasi dari pihak yang memahami atau mengetahui standar kepada pihak yang tidak atau belum memahami standar. Dengan demikian, sosialisasi dapat dipandang sebagai suatu rangkaian belajar mengajar. Dalam proses sosialisasi untuk meningkatkan pengetahuan dan pemahaman pelaku UMKM dalam menyusun laporan keuangan maupun pengelolaan usaha sesuai dengan SAK EMKM diperlukan adanya kontinuitas dan konsistensi untuk mensosialisasikan standar ke seluruh pihak terkait secara menyeluruh di seluruh Indonesia baik dilakukan oleh IAI selaku pembuat standar maupun secara kerjasama dengan institusi lainnya seperti Dinas Koperasi dan UMKM (Anisykurlillah \& Rezqika, 2019; Rudiantoro \& Siregar, 2012). Hal ini dikarenakan bahwa apabila pelaku UMKM mendapatkan informasi dan sosialisasi dengan baik maka pemahaman 
mereka terkait dengan standar akuntansi keuangan yang berlaku akan menjadi lebih baik pula dan mendukung proses impelementasi SAK tersebut. Dengan upaya sosialisasi yang dilakukan dari berbagai sumber seperti media cetak dan media digital, seminar dari berbagi instansi dan lembaga serta pelatihan dengan menghadirkan pembicara yang memahami SAK EMKM diharapkan akan meningkatkan penyusunan laporan keuangan pelaku UMKM yang sesuai dengan SAK EMKM (Adino, 2019). Kontinuitas atau kesinambungan dalam pelaksanaan sosialisasi sangatlah diperlukan untuk meningkatkan pemahaman dan pengetahuan pelaku UMKM mengenai SAK EMKM guna menghasilkan laporan keuangan yang berkualitas. Beberapa penelitian membuktikan bahwa sosialisasi berpengaruh signifikan terhadap implementasi SAK EMKM yaitu penelitian (Adino, 2019; Kusuma \& Lutfiany, 2018). Didukung pula oleh penelitian dari (Anisykurlillah \& Rezqika, 2019; Dewi et al., 2017; Nurdwijayanti \& Sulastiningsih, 2018; Rudiantoro \& Siregar, 2012) membuktikan bahwa sosialisasi berpengaruh terhadap implementasi SAK ETAP.

Berdasarkan uraian di atas, variabel sosialisasi sendiri secara langsung maupun tidak langsung berpengaruh terhadap implementasi SAK EMKM sehingga hipotesis awal dalam KMO dan barlett's test harus terpenuhi dengan asumsi :

$\mathrm{H}_{0}=$ Variabel sosialisasi belum memadai untuk dianalisis lebih lanjut.

$\mathrm{H}_{1}=$ Variabel sosialisasi sudah memadai untuk dianalisis lebih lanjut.

\section{METODE PENELITIAN}

\section{Jenis Penelitian}

Penelitian ini menggunakan pendekatan jenis kuantitatif yang menekankan analisisnya pada data-data numerical (angka) yang diolah dengan metode statistika (Azwar, 2005). Pengumpulan data yang tepat sangat penting dalam penelitian, karena data menentukan baik buruknya suatu penelitian. Pengumpulan data merupakan usaha-usaha untuk memeroleh bahan-bahan dapat dipertanggungjawabkan (Hidayanti et al., 2019). Pengumpulan data dalam penelitian ini dilakukan dengan kuesioner yaitu dengan cara memberi seperangkat pertanyaan atau pernyataan tertulis kepada responden yang dalam hal ini adalah pelaku UMKM yang ada di Kota Mataram yang diukur dengan menggunakan skala likert 5 (lima) poin berikut ini: (a) Skor 1 untuk jawaban "Sangat tidak setuju (STS)"; (b) Skor 2 untuk jawaban "Tidak setuju (TS)"; (c) Skor 3 untuk jawaban "Netral (N)"; (d) Skor 4 untuk jawaban "Setuju (S)"; dan (e) Skor 5 untuk jawaban "Sangat setuju (SS)".

\section{Populasi dan Sampel Penelitian}

Populasi dalam penelitian ini adalah UMKM yang ada di Kota Mataram dengan yang telah terdaftar di Dinas Perindustrian, Koperasi Dan UKM, yaitu UMKM yang memiliki modal di atas Rp15.000.000, telah memiliki izin dan jenis usaha UMKM yang bergerak dibidang perdagangan didapatkan sebanyak 314 UMKM tahun 2019 (Dinas Perindustrian Koperasi dan UKM Kota Mataram). Dalam menentukan jumlah sampel 
penelitian ini menggunakan rumus slovin.

Berdasarkan perhitungan dengan rumus slovin dengan populasi $(\mathrm{N})$ adalah 314 sehingga jumlah sampel minimal adalah 38 UMKM. Karena keterbatasan waktu dan kondisi pihak UMKM yang tidak mengembalikan kuesioner sesuai waktu yang dijadwalkan sehingga sampel yang terkumpul dalam penelitian ini adalah sebanyak 40 UMKM.

\section{Identifikasi dan Definisi Operasional Variabel}

Variabel yang digunakan dalam penelitian ini meliputi :

$\mathrm{X}_{1}$ : Latar Belakang Pendidikan yang didefinisikan sebagai jenjang pendidikan atau tingkat pendidikan yang ditempuh oleh pemilik atau pelaku UMKM.

$\mathrm{X}_{2}$ : Kualitas SDM yang didefinisikan sebagai kompetensi yang dimiliki oleh pelaku UMKM yang terdiri atas keterampilan (skill), pengetahuan (knowledge) dan kemampuan (ability).

$\mathrm{X}_{3}$ : Persepsi kegunaan yangdidefinisikan cara pandang pelaku UMKM mengenai pentingnya penerapan SAK EMKM dalam penyusunan laporan keuangan.

$\mathrm{X}_{4}$ : Persepsi kemudahan penggunaan yang didefinisikasn sebagai cara pandang pelaku UMKM mengenai kemudahan penerapan SAK EMKM dalam mencatat berbagai kejadian atau transaksi ekonomi untuk keperluan penyusunan laporan keuangan.

$\mathrm{X}_{5}$ : Sosialisasi yang didefinisikan sebagai suatu mekanisme penyampaian informasi mengenai SAK EMKM kepada pelaku UMKM sebagai target penggunanya melalui berbagai pola dan bentuk kegiatan, baik secara langsung maupun tidak langsung yang bertujuan untuk membuat pelaku UMKM menjadi tahu bahkan memahami SAK EMKM.

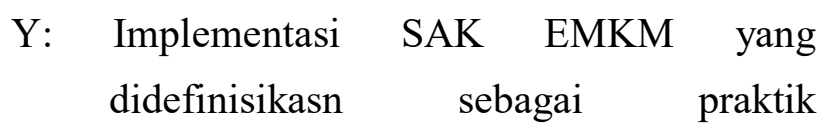
pelaksanaan prosedur akuntansi oleh para pelaku UMKM untuk mencatat setiap transaksi ekonomi dalam kegiatan operasionalnya dengan berpedoman pada SAK EMKM.

\section{Teknik Analisis Data}

Tahapan analisis data dilakukan dengan menggunakan metode analisis faktor yang termasuk salah satu teknik statistika dan dapat digunakan untuk memberikan deskripsi yang relatif sederhana melalui reduksi jumlah variabel yang disebut faktor. Analisis faktor dipergunakan untuk mereduksi data atau meringkas, dari variabel lama yang banyak diubah menjadi sedikit variabel baru yang disebut faktor, dan masih memuat sebagian besar informasi yang terkandung dalam variabel asli (Santoso, 2010). Analisis faktor menerangkan variasi sejumlah variabel asal dengan menggunakan faktor yang lebih sedikit dan yang tidak teramati dengan anggapan bahwa semua variabel awal dapat dinyatakan sebagai kombinasi linier dari faktor faktor itu ditambahkan dengan suku residual. Pada dasarnya, banyak besaran yang tidak teramati sehingga diverifikasi langsung model faktor dari pengamatan $\mathrm{X}_{1}, \mathrm{X}_{2}, \mathrm{X}_{3}, \ldots, \mathrm{X}_{\mathrm{P}}$ pada variabel yang umumnya berkorelasi, faktor yang unik 
tidak berkorelasi dengan sesama faktor yang unik dan juga tidak berkorelasi dengan common factor. Common factor sendiri bisa dinyatakan sebagai kombinasi linear dari variabel-variabel yang terlihat/terobservasi (the observed variables) dari hasil penelitian lapangan, sehingga model pembentukan variabel yang telah direduksi dalam satu faktor digambarkan:

$$
F_{i=} W_{i 1} X_{1}+W_{i 2} X_{2}+W_{i 3} X_{3}+\ldots+W_{i k} X_{k}
$$

\section{Keterangan :}

$$
\begin{array}{ll}
\mathrm{i} & =1,2,3, \ldots, \mathrm{p} \\
\mathrm{k} & =1,2,3, \ldots, \mathrm{p} \\
\mathrm{F}_{\mathrm{i}} & =\text { perkiraan faktor ke-I (didasarkan pada } \\
& \text { nilai variabel X dengan koefisien } \left.\mathrm{W}_{\mathrm{i}}\right) \\
\mathrm{W}_{\mathrm{i}} & =\text { bobot atau koefisien nilai faktor ke-i } \\
\mathrm{k} & =\text { banyaknya variabel }
\end{array}
$$

Dimungkinkan untuk memilih timbangan (weight) atau koefisien nilai faktor (factor score coefficient) sehingga faktor yang pertama menjelaskan sebagian besar porsi seluruh varian atau menyerap sebagian besar varian seluruh variabel. Kemudian set timbangan kedua dapat dipilih, sehingga faktor yang kedua menyerap sebagian besar sisa varian, setelah diambil faktor pertama, dengan syarat bahwa faktor yang kedua tidak berkorelasi (orthogonal) dengan faktor pertama. Prinsip yang sama dapat dipergunakan untuk memilih faktor selanjutnya, sebagai faktor tambahan, yaitu faktor ketiga. Jadi, faktor bisa diperkirakan/diestimasi sehingga nilai faktor yang satu tidak berkorelasi dengan faktor lainnya. Faktor yang diperoleh merupakan variabel baru yang tidak berkorelasi antara satu faktor dengan faktor lainnya, artinya tidak terjadi multi collinearity. Banyaknya faktor lebih sedikit dari banyaknya variabel asli yang dianalisis faktor, sebab analisis faktor memang mereduksi jumlah variabel yang banyak menjadi variabel baru yang jumlahnya lebih sedikit.

Prinsip utama dalam analisis faktor adalah korelasi, maka asumsi-asumsi yang terkait dalam metode statistik adalah: (1) Besar korelasi atau korelasi independent variabel harus cukup kuat; (2) Besar korelasi parsial, korelasi antar dua variabel dengan menanggap tetap variabel lain; dan (3) Pengujian sebuah matriks korelasi diukur dengan besaran barlett test of sphericity atau dengan measure sampling adequacy (MSA).

Tahap pertama dalam analisis faktor adalah dengan menilai mana saja variabel yang dianggap layak untuk dimasukkan dalam analisis selanjutnya. Pengujian ini dilakukan dengan memasukkan semua variabel yang ada, dan kemudian pada variabel-variabel tersebut dikenakan sejumlah pengujian. Logika pengujian adalah jika sebuah variabel memang mempunyai kecenderungan mengelompok dan membentuk sebuah faktor, variabel tersebut akan mempunyai korelasi yang cukup tinggi dengan variabel yang lain. Sebaliknya, variabel dengan korelasi yang lemah dengan variabel yang lain cenderung tidak akan mengelompok dalam faktor tertentu. Selanjutnya, Uji KMO dan Barlett Test, memiliki beberapa hal yaitu angka KMO haruslah berada di atas 0,5 dan signifikan harus berada di bawah 0,05. Sedangkan pada uji MSA angkanya haruslah berada pada 0 sampai 1, dengan kriteria: (1) MSA $=1$, variabel dapat diprediksi tanpa kesalahan oleh variabel lain; (2) MSA > 0,5, variabel masih bisa diprediksi dan bisa 
dianalisis lebih lanjut; dan (3) MSA $<0,5$, variabel tidak bisa diprediksi dan tidak bisa dianalisis lebih lanjut, atau dikeluarkan dari variabel lainnya.

Kemudian setelah sampel didapat dan uji asumsi terpenuhi maka langkah selanjutnya: (1) Melakukan proses inti analisis faktor, yakni factoring, atau menurunkan satu atau lebih faktor dari variabel-variabel yang telah lolos pada uji variabel sebelumnya; (2) Melakukan proses factor rotation atau rotasi terhadap faktor yang terbentuk. Tujuan rotasi untuk memperjelas variabel yang masuk dalam faktor tertentu; (3) Interpretasi atau faktor yang telah terbentuk, yang dianggap bisa mewakili variabel - variabel anggota faktor tertentu; dan (4) Validasi atas hasil faktor untuk mengatahui apakah faktor yang terbentuk telah valid.

Setelah satu atau lebih faktor terbentuk, dengan sebuah faktor berisi sejumlah variabel yang split ditentukan akan masuk ke dalam faktor mana, maka proses selanjutnya adalah dengan melakukan proses rotasi yang akan memperjelas kedudukan.

\section{HASIL DAN PEMBAHASAN Deskripsi Data}

Deskripsi data penelitian ini merupakan identitas responden penelitian yang terdiri dari jenis kelamin, penjualan perusahaan dalam setahun, dan umur usaha UMKM. Identitas responden ini disajikan pada Tabel 1.

\section{Uji Validitas dan Reliabilitas}

Uji validitas adalah ukuran untuk menilai apakah alat ukur yang digunakan benar-benar mampu memberikan nilai dari variabel yang ingin diukur. Butir-butir pernyataan dinyatakan valid jika nilai signifikansi $\mathrm{p}($ sig $)<0,05$. Berdasarkan hasil penelitian ini didapat bahwa semua indikator memiliki nilai signifikansi lebih kecil dari 0,05 sehingga dapat dinyatakan valid. Sedangkan uji reliabilitas digunakan untuk mengukur apakah instrumen tersebut secara konsisten memberikan hasil ukur yang sama tentang sesuatu yang diukur pada waktu yang berlainan. Berdasarkan hasil penelitian, semua indikator kuesioner mempunyai nilai koefisien cronbach alpha lebih besar dari 0,60 sehingga dapat dikatakan bahwa semua indikator adalah reliabel.

Hasil uji validitas dan reliabilitas dari penelitian ini disajikan pada Tabel 2.

\section{Hasil Analisis Faktor}

Analisis faktor yang dilakukan dalam penelitian ini terdiri dari:

1. Tahapan Pertama Pada Analisis Faktor

Tahapan pertama pada analisis faktor adalah menilai variabel mana saja yang dianggap layak (appropriateness) untuk dimasukkan dalam analisis selanjutnya, dengan hipotesis:

$\mathrm{H}_{0}=$ Sampel (variabel) belum memadai untuk dianalisis lebih lanjut.

$\mathrm{H}_{1}=\quad$ Sampel (variabel) sudah memadai untuk dianalisis lebih lanjut.

Kriteria pengambilan keputusan yaitu dengan melihat probabilitas (signifikasi), jika nilai sig> 0,05 Ho 
diterima, dan nilai sig $<0,05$ maka Ho ditolak.

Hasil uji Tahapan Pertama ini disajikan pada Tabel 3 .

Tabel 1

Identitas Responden

\begin{tabular}{llrr}
\hline \multicolumn{2}{c}{ Karakteristik Responden } & Jumlah & Persentase \\
\hline Jenis & Laki laki & 18 & $45 \%$ \\
Kelamin & Perempuan & 22 & $55 \%$ \\
Penjualan & < Rp100 Juta & 12 & $30 \%$ \\
Perusahaan & Rp100 Juta - & 23 & $57,5 \%$ \\
dalam & Rp499 Juta & 5 & $12,5 \%$ \\
Setahun & Rp500 Juta - & & \\
& Rp2,5 & & \\
& Miliyar & & \\
Umur Usaha & 1-3 tahun & 6 & $15 \%$ \\
& 4-6 tahun & 14 & $35 \%$ \\
& $7-9$ tahun & 12 & $30 \%$ \\
& $>10$ tahun & 8 & $20 \%$ \\
\hline
\end{tabular}

Sumber: Data diolah oleh peneliti, Tahun 2020

Tabel 2

Hasil Uji Validitas dan Reliabilitas

\begin{tabular}{cccc}
$\begin{array}{c}\text { Butir } \\
\text { Pertanyaan } \\
\text { Tiap } \\
\text { Variabel }\end{array}$ & $\begin{array}{c}\text { Nilai } \\
\text { Cronbach's } \\
\text { Alpha }\end{array}$ & $\begin{array}{c}\text { Koefisien } \\
\text { korelasi }\end{array}$ & $\begin{array}{c}\text { Nilai Signifikasi } \\
\text { Terhadap Total } \\
\text { Tiap Butir } \\
\text { Pertanyaan }\end{array}$ \\
\hline $\mathrm{Y}_{1.1}$ & 0,724 & 0,797 & 0,004 \\
$\mathrm{Y}_{1.2}$ & 0,699 & 0,788 & 0,006 \\
$\mathrm{Y}_{1.3}$ & 0,705 & 0,810 & 0,000 \\
$\mathrm{Y}_{1.4}$ & 0,699 & 0,771 & 0,003 \\
$\mathrm{Y}_{1.5}$ & 0,698 & 0,809 & 0,000 \\
$\mathrm{X}_{1.1}$ & 0,712 & 1,000 & 0,000 \\
$\mathrm{X}_{2.1}$ & 0,705 & 0,884 & 0,000 \\
$\mathrm{X}_{2.2}$ & 0,703 & 0,805 & 0,000 \\
$\mathrm{X}_{3.1}$ & 0,718 & 0,542 & 0,008 \\
$\mathrm{X}_{3.2}$ & 0,717 & 0,651 & 0,001 \\
$\mathrm{X}_{3.3}$ & 0,720 & 0,550 & 0,000 \\
$\mathrm{X}_{3.4}$ & 0,720 & 0,449 & 0,000 \\
$\mathrm{X}_{3.5}$ & 0,709 & 0,655 & 0,000 \\
$\mathrm{X}_{3.6}$ & 0,719 & 0,516 & 0,004 \\
$\mathrm{X}_{3.7}$ & 0,725 & 0,328 & 0,000 \\
$\mathrm{X}_{3.8}$ & 0,730 & 0,193 & 0,000 \\
$\mathrm{X}_{4.1}$ & 0,708 & 0,824 & 0,014 \\
$\mathrm{X}_{4.2}$ & 0,704 & 0,862 & 0,003 \\
$\mathrm{X}_{4.3}$ & 0,700 & 0,768 & 0,007 \\
$\mathrm{X}_{5.1}$ & 0,639 & 0,884 & 0,000 \\
$\mathrm{X}_{5.2}$ & 0,763 & 0,751 & 0,000 \\
$\mathrm{X}_{5.3}$ & 0,621 & 0,843 & 0,000 \\
\hline $\mathrm{S}_{3.1}$ & $\mathrm{Dat}$ & \\
\hline
\end{tabular}

Sumber: Data diolah oleh peneliti, Tahun 2020
Tabel 3

Hasil Uji Tahap Pertama (KMO dan Barleet's)

\begin{tabular}{llr}
\hline $\begin{array}{l}\text { Kaiser-Meyer-Olkin Measure of Sam- } \\
\text { pling Adequacy. }\end{array}$ & 0,493 \\
\hline $\begin{array}{l}\text { Bartlett's Test } \\
\text { of Sphericity }\end{array}$ & Approx. Chi-Square & 24,342 \\
& Df & 10 \\
& Sig. & 0,007 \\
\hline
\end{tabular}

Sumber: Data diolah oleh peneliti, Tahun 2020

Pada output di atas terlihat Angka KMO dan barlett's test adalah 0,493 dengan signifikansi 0,001 karena angka tersebut sudah di atas 0,5 dan signifikansi jauh di bawah $0,05(0,007<0,05)$ maka $\mathrm{H}_{0}$ ditolak sehingga keseluruhan variabel dan sampel yang ada sudah dapat dianalisis dengan analisis faktor, kemudian tahap selanjutnya adalah menganalisis output anti image matrices.

Tahapan selanjutnya adalah menganalisis Variabel dengan MSA (Measure of Sampling Adequacy). Pada tahapan ini variabel di uji untuk melihat apakah variabel dapat dianalisis lebih lanjut atau dikeluarkan. Dengan kriteria angka MSA (Measure of Sampling Adequacy) berkisar 0 sampai 1 dengan kriteria (Santoso, 2010): (a) Kriteria 1: $\mathrm{MSA}=1$, variabel tersebut dapat diprediksi tanpa kesalahan oleh variabel yang lain; (b) Kriteria 2: MSA >0,5, variabel tersebut bisa diprediksi dan bisa dianalisis lebih lanjut; (c) Kriteria 3: MSA $<0,5$, variabel tersebut tidak bisa diprediksi dan tidak bisa dianalisis lebih lanjut. 
Jika seandainya ada lebih dari satu variabel yang mempunyai MSA dibawah 0,5 maka yang dikeluarkan adalah variabel dengan MSA terkecil kemudian proses pengujian tetap diulang lagi.

Hasil uji MSA Tahap 1 disajikan pada Tabel 4.

Tabel 4

Hasil Uji MSA Tahap 1

\begin{tabular}{lcr}
\hline \multicolumn{1}{c}{ Variabel } & $\begin{array}{c}\text { Nilai } \\
\text { MSA }\end{array}$ & $\begin{array}{c}\text { Standar } \\
\text { Minimum }\end{array}$ \\
\hline Latar_belakang_pendidikan & 0,491 & 0,5 \\
Kualitas_SDM & 0,489 & 0,5 \\
Persepsi_kegunaan & 0,505 & 0,5 \\
Persepsi_kemudahan_peng- & 0,520 & 0,5 \\
gunaan_ & & \\
Sosialisasi & 0,345 & 0,5 \\
\hline Sumber: Data dian
\end{tabular}

Sumber: Data diolah oleh penulis, Tahun 2020

Pada tabel di atas perhatikan bagian anti image correlation pada angka bertanda a terlihat untuk variabel latar belakang pendidikan bernilai 0,491, untuk kualitas SDM 0,489 kemudian variabel persepsi kegunaan 0,505, untuk variabel persepsi kemudahan penggunaan adalah 0,520 dan terakhir variabel sosialisasi bernilai 0,345. Dapat dilihat dari kelima variabel yang diuji beberapa variabel bernilai dibawah 0,5 sehingga variabel yang akan dikeluarkan adalah variabel dengan nilai MSA terkecil 0,345, maka variabel sosialisasi dikeluarkan kemudian akan dilakukan pengujian ulang dengan variabel yang tersisa, sehingga didapatkan output seperti yang disajikan pada Tabel 5 .

Hasil pada Tabel 5 menunjukkan angka KMO dan Barlett's Test adalah 0,530 dengan signifikasi 0,001 karena angka tersebut sudah di atas 0,5 dan signifikasi jauh di bawah $0,05(0,001<0,05)$ maka $\mathrm{H}_{0}$ ditolak sehingga variabel dan sampel yang ada sudah dapat dianalisis dengan analisis faktor, kemudian tahap selanjutnya adalah menganalisis output Anti Image Matrices, seperti yang disajikan pada Tabel 6 .

Tabel 5

\begin{tabular}{|c|c|c|}
\hline \multicolumn{3}{|c|}{$\begin{array}{r}\text { Hasil Uji Tahap Pertama (KMO dan } \\
\text { Setelah Pengujian Ulang }\end{array}$} \\
\hline $\begin{array}{l}\text { Kaiser-Meyer } \\
\text { pling Adequac }\end{array}$ & lkin Measure of Sam- & 0,530 \\
\hline \multirow{3}{*}{$\begin{array}{l}\text { Bartlett's Test } \\
\text { of Sphericity }\end{array}$} & Approx. Chi-Square & 21,515 \\
\hline & $D f$ & 6 \\
\hline & Sig. & 0,001 \\
\hline
\end{tabular}

Sumber: Data diolah oleh peneliti, Tahun 2020

Tabel 6

Hasil Uji MSA Tahap 1 Setelah Pengujian Ulang

\begin{tabular}{lcr}
\hline \multicolumn{1}{c}{ Variabel } & $\begin{array}{c}\text { Nilai } \\
\text { MSA }\end{array}$ & $\begin{array}{c}\text { Standar } \\
\text { Minimum }\end{array}$ \\
\hline Latar_belakang_pendidikan & 0,530 & 0,5 \\
Kualitas_SDM & 0,552 & 0,5 \\
Persepsi_kegunaan & 0,526 & 0,5 \\
Persepsi_kemudahan_peng- & 0,523 & 0,5 \\
gunaan & & \\
\hline
\end{tabular}

Sumber: Data diolah oleh peneliti, Tahun 2020

Terlihat pada tahap kedua setelah variabel sosialisasi dikeluarkan, terjadi peningkatan nilai MSA keseluruhan nilai pada variabel berada di atas 0,5. Untuk latar belakang pendidikan 0,530, kualitas SDM 0,552 dan persepsi kegunaan 0,526 serta variabel persepsi kemudahan penggunaan sebesar 0,523 sehingga dapat dianalisis lebih lanjut. 
2. Tahap Kedua Analisis Faktor - Proses Factoring dan Rotasi

Selanjutnya dilakukan proses inti analisis faktor, yakni melakukan ektraksi terhadap sekumpulan variabel yang ada, sehingga terbentuk satu atau lebih faktor dengan principal component analysis sebagai metode extraction dan menggunakan metode rotasi varimax. Hasilnya dapat dilihat pada beberapa output yang disajikan pada Tabel 7 s.d. Tabel 10.

\section{Tabel 7}

Hasil Output Communalities

\begin{tabular}{lcr}
\hline & Initial & Extraction \\
\hline Latar_belakang_pendidikan & 1,000 & 0,714 \\
Kualitas_SDM & 1,000 & 0,685 \\
Persepsi_kegunaan & 1,000 & 0,779 \\
Persepsi_kemudahan_penggunaan & 1,000 & 0,780 \\
Extraction Method: Principal Component Analysis & \\
\hline
\end{tabular}

Sumber: Data diolah oleh peneliti, Tahun 2020

Pada output communalities di atas pada dasarnya adalah jumlah varians dari suatu variabel mula-mula yang bisa dijelaskan oleh faktor yang ada. Dapat dilihat nilai extraction sekitar 71,4\% varians dari variabel latar belakang Pendidikan, 68,5\% varians dari kualitas SDM, 77,9\% varians persepsi kegunaan dan $78 \%$ varians dari variabel persepsi kemudahan penggunaan bisa dijelaskan oleh faktor yang terbentuk, dengan ketentuan bahwa semakin besar communalities sebuah variabel berarti semakin erat hubungannya dengan faktor yang terbentuk. Faktor yang terbentuk dapat dilihat dari nilai eigenvalue pada output total variance explained.
Tabel 8

Hasil Ekstraksi PCA

\begin{tabular}{lccc}
\hline \multirow{2}{*}{\multicolumn{1}{c}{ Component/Variable }} & \multicolumn{3}{c}{ Initial Eigenvalues } \\
& Total & Total \\
\hline Latar_belakang_pendidikan & 1,737 & 1 & 1,737 \\
Kualitas_SDM & 1,221 & 2 & 1,221 \\
$\begin{array}{l}\text { Persepsi_kegunaan } \\
\begin{array}{l}\text { Persepsi_kemudahan_penggu- } \\
\text { naan }\end{array}\end{array}$ & 0,612 & 3 & 0,612 \\
\hline
\end{tabular}

Sumber: Data diolah oleh peneliti, Tahun 2020

Hasil ekstraksi PCA merupakan tabel hasil ekstraksi dari sejumlah variabel yang mempengaruhi dalam determinasi implementasi standar akuntansi keuangan entitas mikro kecil dan menengah (SAK EMKM). Total variabel yang memiliki korelasi adalah 4 variabel, selanjutnya pada Tabel 9 total hasil ekstraksi, akan terlihat jumlah faktor hasil ekstraksi.

\section{Tabel 9}

\section{Jumlah Faktor Hasil Ekstraksi (PCA)}

\begin{tabular}{ccc}
\hline \multicolumn{3}{c}{ Extraction Sums of Squared Loadings } \\
\hline Total & \% of Variance & Cumulative \% \\
\hline 1.737 & 43,431 & 43,431 \\
1.221 & 30,535 & 73,966 \\
\hline
\end{tabular}

Sumber: Data diolah oleh peneliti, Tahun 2020

Dapat dijelaskan di atas yang berhubungan langsung dengan Tabel 8, ada 4 variabel diekstrak menjadi 2 faktor karena dengan 2 faktor terbentuk angka eigenvalues di atas 1, yakni 1,737 dan 1,221. Setelah diketahui bahwa 2 faktor adalah jumlah yang paling optimal, tabel output component matriks menunjukkan 
distribusi keempat variabel tersebut pada dua faktor yang terbentuk.

Tabel 10

Output Component Matriks

\begin{tabular}{lrc}
\hline & \multicolumn{2}{c}{ Component } \\
\cline { 2 - 3 } & \multicolumn{1}{c}{1} & 2 \\
\hline Latar_belakang_pendidikan & $-0,013$ & 0,845 \\
Kualitas_SDM & 0,155 & 0,813 \\
Persepsi_kegunaan & 0,875 & 0,118 \\
Persepsi_kemudahan_penggunaan & 0,883 & 0,027 \\
Extraction Method: Principal & \multicolumn{2}{c}{ Component } \\
Analysis. Method: Varimax & with & Kaiser \\
Rotation Mnalization. & & \\
Normalion & & \\
a. Rotation converged in 3 iterations & & \\
\hline
\end{tabular}

Sumber: Data diolah oleh peneliti, Tahun 2020

Berdasarkan tabel di atas maka model analisis faktor yang terbentuk adalah:

$$
\begin{aligned}
& F_{1}=0,875 X_{3}+0,883 X_{4} \\
& F_{2}=0,845 X_{1}+0,813 X_{2}
\end{aligned}
$$

\section{Pembahasan}

Berdasarkan hasil analisa data yang telah dilakukan, diperoleh hasil bahwa variabel sosialisasi tidak dapat dianalisis lebih lanjut dikarenakan bahwa pada tahapan anti image matrix, nilai MSA variabel sosialisasi sebesar 0,345 lebih kecil dari 0,5 sehingga variabel sosialisasi dikeluarkan dan kemudian akan dilanjutkan pengujian ulang dengan variabel yang tersisa. Setelah dilakukannya proses rotasi terlihat perbedaan secara nyata dan dapat dipahami melalui model analisis faktor di atas bahwa pada nilai faktor loadingsnya terlihat bahwa faktor 1 terdiri dari variabel persepsi kegunaan dan variabel persepsi kemudahan penggunaan karena nilai korelasi variabel persepsi kegunaan adalah 0,875 dan variabel persepsi kemudahan penggunaan adalah 0,883. Kemudian faktor 2 terdiri dari variabel latar belakang pendidikan dan kualitas SDM karena nilai korelasi variabel latar belakang pendidikan menjadi lebih besar 0,845 dan variabel kualitas SDM sebesar 0,813. sehingga dari keempat variabel telah direduksi menjadi hanya terdiri dari 2 faktor. Variabel-variabel yang telah dikelompokkan diberi nama, dimana nama faktor tergantung dari variabel yang membentuknya, sehingga pemberian nama ini bersifat subjektif serta tidak ada ketentuan yang pasti mengenai pemberian nama tersebut. Pemberian nama faktor dijelaskan sebagai berikut:

\section{Faktor 1 yaitu Persepsi Pelaku UMKM}

Faktor 1 terbentuk dari variabel persepsi kegunaan dan variabel persepsi kemudahan penggunaan dari SAK EMKM jika diberi nama faktor menjadi persepsi pelaku UMKM. Hal ini berarti kemampuan untuk merasakan, memahami jiwa, objek-objek, maupun kualitas melalui pemaknaan rasa, kesadaran, perbandingan pengetahuan intuisi yang dalam ataupun kemampuan panca indra dalam memahami sesuatu, pengertian, pengetahuan yang diterima oleh pelaku UMKM berkaitan dengan pemahaman tentang kemudahan dan penggunaan SAK EMKM. Karena korelasi variabel persepsi kegunaan dan variabel persepsi kemudahan penggunaan adalah positif dengan nilai korelasi antara variabel persepsi kegunaan pada faktor 1 adalah 
$(+0,875)$ dan $(+0,883)$ dapat dijelaskan bahwa para pelaku UMKM yang ada di Kota Mataram pada prinsipnya memiliki persepsi kegunaan atas SAK EMKM yang baik. Pelaku UMKM meyakini bahwa SAK EMKM sebagai standar akuntansi keuangan yang berlaku dalam penyusunan laporan keuangan sangatlah berguna dan bermanfaat dalam menghasilkan laporan keuangan yang berkualitas dan sesuai standar sehingga dalam pengambilan keputusan oleh pelaku UMKM dirasakan sangat akurat dan tepat karena menyajikan data yang sebenarnya sesuai kondisi UMKM yang dikelola.

Di sisi lain, laporan keuangan yang merupakan bahan pertanggungjawaban kepada pihak-pihak yang berkepentingan dengan perusahaan, ketika SAK EMKM diimplementasikan dalam penyusunan laporan keuangan maka dapat menjadi daya tarik tersendiri bagi pihak-pihak yang akan berinvestasi atau menanamkan modalnya pada perusahaan terutama ketika pelaku UMKM akan mengajukan kredit kepada pihak perbankan sebab pelaku UMKM dapat menyajikan laporan keuangan dapat memberikan informasi tentang posisi keuangan, kinerja dan arus kas yang bermanfaat bagi pengguna laporan keuangan. Sementara itu, persepsi kemudahan penggunaan menunjukkan bahwa para pelaku UMKM di Kota Mataram meyakini bahwa SAK EMKM mudah dan cepat untuk dimengerti dan selanjutnya dapat implementasikan dalam penyusunan laporan keuangan mengingat bahwa SAK EMKM adalah standar akuntansi keuangan yang sesuai dengan kebutuhan pelaku UMKM sehingga ke depannya perlu pelatihan yang terprogram dengan baik dan berkelanjutan mengenai implementasi SAK EMKM. Dapat disimpulkan bahwa persepsi seseorang timbul karena adanya beberapa stimulus yang mempengaruhi persepsi seperti sikap, kebiasaan maupun kemauan dimana jika implementasi SAK EMKM ketika dirasa memudahkan dan memberikan kegunaan untuk menghasilkan laporan keuangan yang berkualitas maka pemilik UMKM dapat mengimplementasikan SAK tersebut. Sebagaimana hasil penelitian yang telah dilakukan sebelumnya oleh (Kusuma \& Lutfiany, 2018) membuktikan bahwa persepsi pelaku UMKM berpengaruh positif dan signifikan terhadap implementasi SAK EMKM. Didukung pula oleh penelitian (Dewi et al., 2017; Tarmizi \& Bugawanti, 2013) bahwa persepsi pelaku UMKM berpengaruh terhadap penggunaan standar akuntansi keuangan yang berlaku.

2. Faktor 2 yaitu Sumber Daya Manusia

Faktor 2 terbentuk dari variabel latar belakang pendidikan dan kualitas SDM jika diberi nama faktor tersebut dapat diberi nama faktor SDM (sumber daya manusia). Hal ini berarti kemampuan, keterampilan, kompetensi serta latar belakang pendidikan 
pelaku UMKM mempengaruhi kualitas laporan keuangan yang dihasilkan sesuai dengan standar akuntansi keuangan entitas mikro kecil dan menengah (SAK EMKM) pada Usaha Mikro Kecil Menengah (UMKM) Di Kota Mataram. Karena korelasi variabel latar belakang pendidikan dan kualitas SDM adalah positif dengan nilai korelasi antara variabel latar belakang pendidikan pada faktor $2(+0,845)$ dan korelasi antara variabel kualitas SDM faktor $2(+0,813)$ maka hal ini berarti bahwa semakin tinggi kualitas sumber daya manusia yang dimiliki dan didukung dengan latar belakang pendidikan atau jenjang pendidikan yang dimiliki oleh pelaku UMKM akan memberikan pemahaman yang lebih baik mengenai implementasi SAK EMKM sehingga hal ini tentunya akan semakin memudahkan para pelaku UMKM dalam membuat laporan keuangan berbasis SAK EMKM. Jika dilihat dari data pelaku UMKM yang ada di Kota Mataram menunjukkan mayoritas tingkat pendidikan pelaku UMKM telah memadai yang berarti pelaku UMKM telah memiliki pengetahuan yang cukup dalam menjalankan usahanya dan mampu mengakses informasi untuk mengembangkan usaha termasuk tentang SAK EMKM. Di sisi lain, usaha yang dijalankan sebagian besar juga telah lebih dari 5 tahun yang berarti bahwa pelaku UMKM telah memiliki pengalaman dalam dunia usaha yang ditekuni. Dengan demikian, kualitas laporan keuangan akan meningkat apabila didukung oleh personel atau sumber daya manusia yang memahami standar akuntansi keuangan ditandai dengan kompetensi, keterampilan dan latar belakang pendidikan yang memadai pelaku UMKM. Sebagaimana hasil penelitian yang dilakukan oleh (Minarni \& Sisdiyantoro, 2014) dan sejalan dengan hasil penelitian (Oktaviyanti et al., 2017) bahwa kualitas sumber daya manusia mempengaruhi implementasi SAK EMKM.

\section{KESIMPULAN DAN SARAN}

Berdasarkan hasil pembahasan yang telah diuraikan sebelumnya, hasil penelitian ini dapat menyimpulkan bahwa variabel yang digunakan untuk menganalisis pengaruhnya terhadap implementasi SAK-EMKM yaitu latar belakang pendidikan, kualitas SDM, persepsi kegunaan, kemudahan penggunaan dan sosialisasi direduksinya menjadi empat variabel dan terbentuk menjadi dua faktor yakni faktor 1 (faktor persepsi UMKM) terdiri atas variabel persepsi kegunaan dan variabel persepsi kemudahan penggunaan dari SAK EMKM dan faktor 2 (faktor sumber daya manusia) terdiri dari variabel latar belakang pendidikan dan kualitas SDM. Dengan demikian, faktor yang mempengaruhi pelaku UMKM di Kota Mataram dalam implementasi SAK EMKM terdiri dari persepsi pelaku UMKM dan sumber daya manusia. Setelah dilakukan analisis lebih lanjut, kedua faktor tersebut memiliki korelasi positif yang berarti memiliki pengaruh dalam 
implementasi SAK EMKM. Hal ini berarti bahwa pada prinsipnya persepsi pelaku UMKM terhadap implementasi SAK EMKM baik dan menganggap bahwa SAK EMKM memiliki kegunaan dan kemudahan dalam penyusunan laporan keuangan yang berkualitas sehingga menghasilkan informasi yang relevan dan reliabel. Di samping itu, sumber daya manusia yang dalam hal ini adalah pelaku UMKM di Kota Mataram memiliki latar belakang pendidikan yang memadai dan sudah memiliki pengalaman dalam dunia usaha yang ditekuni sehingga penyusunan laporan keuangan yang sesuai SAK EMKM dapat diimplementasikan.

Penelitian ini terbatas pada UMKM yang ada di Kota Mataram untuk melihat sejauh mana faktor-faktor yang digunakan dapat mempengaruhi implementasi SAK EMKM sehingga tidak dapat digeneralisir untuk semua wilayah yang ada di NTB dikarenakan wilayah yang berbeda tentu memiliki karakteristik berbeda pula sehingga perlu dilakukan analisis lanjutan pada objek yang berbeda. Pelaku UMKM diharapkan terus mengupgrade SDM yang dimiliki dalam upaya pengimplementasian standar akuntansi keuangan yang berlaku sehingga ke depannya dapat melakukan pencatatan ataupun pembukuan sesuai aturan tersebut. Persepsi yang menganggap sulit pembukuan haruslah ditindaklanjuti dengan mengikuti pelatihan-pelatihan yang diselenggarakan oleh pihak instansi atau dewan pembuat standar sehingga dapat menambah wawasan mengenai pentingnya pembukuan dalam pengelolaan usaha untuk nantinya dapat digunakan dalam pengambilan keputusan. Bagi peneliti selanjutnya yang ingin mengkaji masalah sejenis dapat dijadikan referensi dengan menambah variabel lain dan mengembangkan penelitian ini dengan analisis yang lain.

\section{DAFTAR PUSTAKA}

Adino, I. (2019). Faktor-Faktor Yang Mempengaruhi Pemahaman Pelaku UMKM Terhadap SAK EMKM : Survey Pada UMKM Yang Terdaftar Di Dinas Koperasi Dan UKM Kota Pekanbaru. Jurnal Akuntansi Kompetif, 2(3), 84-94. https://doi.org/10.35446/ akuntansikompetif.v2i3.388

Anisykurlillah, I., \& Rezqika, B. (2019). Faktor Yang Mempengaruhi Implementasi SAK ETAP Pada UMKM Dengan Ketidakpastian Lingkungan Sebagai Variabel Moderasi. Jurnal Riset Keuangan Dan Akuntansi, 5(4), 18-35. https://doi.org/10.25134/jrka.v5i1.1879

Awalia, N., Yuliati, N. N., \& Fauzi, A. K. (2018). Penerapan Informasi Akuntansi Pada UMKM Di Kecamatan Sekarbela Kota Mataram. Jurnal Aplikasi Akuntansi, 2(2), 59-75. http://jaa.unram.ac.id/ index.php/jaa/article/view/21/18

Azwar, S. (2005). Metode Penelitian. Pustaka Belajar.

Dewi, N. A. P. U., Yuniarta, G. A., \& Wahyuni, M. A. (2017). Pengaruh Sosialisasi SAK ETAP, Tingkat Pendidikan Pemilik, dan Persepsi Pelaku UKM terhadap Penggunaan SAK ETAP pada UKM di Kecamatan Buleleng. E-Journal S1 Ak Universitas Pendidikan Ganesha, 7(1).

Hidayanti, A. A., Apriana, D., \& Amrul, R. (2019). Analisis Faktor Yang Mempengaruhi Optimalisasi Kegiatan Budidaya Ayam Kampung Sebagai Upaya Peningkatan Ekonomi Rumah Tangga Kelompok Wanita Tani (KWT) Dusun 
Medain Narmada. Media Bina Ilmiah, 14 (3), 2231-2242. https:// ejurnal.binawakya.or.id/index.php/MBI/ article/view/436/pdf

Ikatan Akuntan Indonesia. Standar Akuntansi Keuangan Entitas Mikro Kecil Menengah. 2016. Jakarta: Ikatan Akuntan Indonesia.

Ikatan Akuntan Indonesia. Standar Akuntansi Keuangan Entitas Tanpa Akuntabilitas Publik. 2009. Jakarta: Ikatan Akuntan Indonesia.

Ikatan Akuntan Indonesia. Pedoman Standar Akuntansi Keuangan No. 01 Revisi 2009.

Kirowati, D., \& Amir, V. (2019). Implementasi Standar Akuntansi Keuangan Entitas Mikro, Kecil dan Menengah (SAK EMKM) Pada Laporan Keuangan di Era Revolusi Industri 4.0 (Studi Kasus Pada UMKM di Kota Madiun). Jurnal AKSI (Akuntansi Dan Sistem Informasi), 4(1), 48-58.

Kusuma, I. C., \& Lutfiany, V. (2018). Persepsi UMKM Dalam Memahami SAK EMKM. Jurnal Akunida, 4(2), 1-14. https:// doi.org/10.30997/jakd.v4i2.1550

Lutfiaazahra, A. (2015). Implementasi Standar Akuntansi Keuangan Entitas Tanpa Akuntabilitas Publik (SAK ETAP) Pada UMKM Pengrajin Batik di Kampoeng Batik Laweyan Surakarta. Prosiding Seminar Nasional Pendidikan Ekonomi \& Bisnis Fakultas Keguruan Dan Ilmu Pendidikan Universitas Sebelas Maret Surakarta, November. http:// snpe.fkip.uns.ac.id

Minarni, E., \& Sisdiyantoro, K. (2014). FaktorFaktor Yang Mempengaruhi Implementasi Standar Akuntansi Keuangan Entitas Tanpa Akuntabilitas Publik (Studi Empiris Pada Koperasi Di Kabupaten Tulungagung). Jurnal Universitas Tulungagung Bonorowo, 2(1), 1-12.

Mubiroh, S., \& Ruscitasari, Z. (2020). Implementasi SAK EMKM dan Pengaruhnya Terhadap Penerimaan Kredit UMKM. Berkala Akuntansi Dan Keuangan
Indonesia, 4(2), 1-15. https:// doi.org/10.20473/baki.v4i2.15265

Munandar, W. A., \& Hidayatulloh, A. (2019). Determinan Kebutuhan Standar Akuntansi Keuangan Entitas Tanpa Akuntabilitas Publik. Assets: Jurnal Akuntansi Dan Pendidikan, 8(1), 70-77. https://doi.org/10.25273/jap.v8i1.3311

Nurdwijayanti, N., \& Sulastiningsih, S. (2018). Analisis Faktor-Faktor Yang Mempengaruhi Implementasi Standar Akuntansi Keuangan Entitas Tanpa Akuntabilitas Publik (SAK ETAP) Pada UMKM (Studi Kasus Pada UMKM Di Suryodiningratan Mantrijeron Yogyakarta). Jurnal Riset Akuntansi Mercu Buana, 4(1), 35-50. https:// doi.org/10.26486/jramb.v4i1.496

Oktaviyanti, P. M., Herawati, N. T., \& Atmadja, A. W. T. (2017). Pengaruh Pengendalian Internal, Kompetensi Sumber Daya Manusia, Dan Budaya Etis Organisasi Terhadap Kualitas Laporan Keuangan (Studi Kasus Koperasi Simpan Pinjam Di Kecamatan Buleleng). EJournal S1 Ak Universitas Pendidikan Ganesha, 8(2).

Partomo, T. S., \& Soejoedono, A. R. (2002). Ekonomi Skala Kecil/Menengah dan Koperasi (1st ed.). Ghalia Indonesia.

Peraturan Bank Sentral Nomor 14/22/PBI/2012 Tentang Pemberian Kredit Oleh Bank Umum Dan Bantuan Teknis Dalam Rangka Pengembangan Usaha Mikro, Kecil Dan Menengah.

Pinasti, M. (2007). Pengaruh Penyelenggaraan Dan Penggunaan Informasi Akuntansi Terhadap Persepsi Pengusaha Kecil Atas Informasi Akuntansi : Suatu Riset Eksperimen. Simposium Nasional Akuntansi X, 1-21.

Prajanto, A., \& Septriana, I. (2018). Implementasi Penerapan SAK EMKM serta Dampaknya pada Kualitas Pelaporan Keuangan UMKM (Studi Kasus Pada UMKM Se Kota Semarang). Jurnal ASET, 20(2), 79-89. 
Pratiwi, N. B., \& Hanafi, R. (2016). Analisis Faktor Yang Mempengaruhi Penerapan Standar Akuntansi Keuangan Entitas Tanpa Akuntabilitas Publik (SAK ETAP) Pada Usaha Mikro Kecil Dan Menengah (UMKM). Jurnal Akuntansi Indonesia, 5 (1), 79-98. https://doi.org/10.30659/ jai.5.1.79-98

Riduwan. (2010). Metode \& Teknik Menyusun Proposal Penelitian : Untuk Mahasiswa S1, S2, dan S3 (3rd ed.). Alfabeta.

Robbins, S. P. (2002). Prinsip-Prinsip Perilaku Organisasi (D. Sartika (ed.); 5th ed.). Erlangga.

Rudiantoro, R., \& Siregar, S. V. (2012). Kualitas Laporan Keuangan UMKM Serta Prospek Implementasi SAK ETAP. Jurnal Akuntansi Dan Keuangan Indonesia, 9(1), 1-21. https://doi.org/10.21002/jaki.2012.01

Santoso, S. (2010). Statistik Multivariat: Konsep dan Aplikasi dengan SPSS. Elex Media Komputindo.

Sariningtyas, P., \& W, T. D. (2011). Standar Akuntansi Keuangan Entitas Tanpa Akuntabilitas Publik Pada Usaha Kecil dan Menengah. Jurnal Akuntansi Keperilakuan Indonesia, 1(1), 90-101.

Soraya, E. A., \& Mahmud, A. (2016). FaktorFaktor Yang Mempengaruhi Kebutuhan Standar Akuntansi Keuangan Entitas Tanpa Akuntabilitas Publik. Accounting Analysis Journal, 5(1), 1-8.

Susanto, B., \& Yuliani, N. L. (2015). Prospek Implementasi SAK ETAP Berbasis Kualitas Laporan Keuangan UMKM. Optimum: Jurnal Ekonomi Dan Pembangunan, 5(1), 1-17. https:// doi.org/10.12928/optimum.v5i1.7796

Tambunan, T. T. (2009). UMKM di Indonesia. Ghalia Indonesia.

Tarmizi, R., \& Bugawanti, N. L. S. (2013). Pengaruh Persepsi Pengusaha Kecil Dan Menengah Terhadap Penggunaan SAK ETAP Di Kota Bandar Lampung (Studi
Pada Sentra Kripik Segalamider Bandar Lampung). Jurnal Akuntansi Dan Keuangan, 4(2). https://doi.org/10.36448/ jak.v4i2.418

Undang-Undang Nomor 20 Tahun 2003 Tentang Sistem Pendidikan Nasional.

Undang-Undang Nomor 20 Tahun 2008 tentang Usaha Mikro Kecil Dan Menengah (UMKM) 